\title{
Gerardo Chávez y el espejo de nuestra cultura
}

\author{
NANDA LEONARDINI \\ Departamento Académico de Arte
}

Hay golpes en la vida, tan fuertes... ;Yo no sé! Golpes como el odio de Dios; como si ante ellos, la resaca de todo lo sufrido se empozara en el alma... ;Yo no sé!

César Vallejo

(Fragmento de Los heraldos negros)

IE n el departamento de La Libertad, Perú, existe uno de los innumerables Es territorios milenarios, donde se desarrollan algunas de las tantas civilizaciones de la antigüedad que enriquecen la historia peruana. Allí nacen y mueren culturas como Moche, Sipán, Chimú, reconocidas por un avanzado desarrollo tecnológico que a la fecha pervive a través de una ingeniería hidráulica dueña de una red de canales aptospara trasladarel dgua de un valle a otro sorteando todo tipo de obstáculos; de ung sofisticada metalurgia capaz de obtener aleaciones como el bronce arsenical para elaborar armas de guerra o la tumbaga (oro, plata y cobre) a fin de crear hermosas joyas; de una imponente arquitectura en adobe tributado para erigir con ellos centros ceremoniales y administrativos decorados con policromados murales o sobre relieves; de una exquisita cerámica bruñida, escultórica, bícroma o monocroma, verdaderos documentos que relatan pasajes históricos, mitológicos, hablan de costumbres, arquitectura, vestimenta, flora y fauna.

Este desenvolvimiento cultural es interrumpido brutalmente por los españoles quienes fundan Trujillo, convirtiéndose con el transcurrir de los siglos en una de las más importantes urbes del norte peruano. En esta primorosa ciudad la hidalguía hispana aún perdura en huellas como la traza cuadricular, así como en uno de los baluartes de la antigua muralla defensora de la población religiosa y civil, quienes dejan como testimonio de su poder económico, político y social numerosos inmuebles. Entre estos edificios, que hoy día conforman parte del 
patrimonio cultural, destacan iglesias y casonas. Las primeras, levantadas por diferentes órdenes regulares, se convierten en espacios sagrados repletos de retablos barrocos invadidos por santos, ángeles, querubines, rosas y oro, en tanto las segundas hablan del esplendor económico de una minoría privilegiada, manifestada en el lujo de sus fachadas donde se ostentan encajes bordados de fierro forjado, balcones de antepecho o de cajón cerrados con celosías y portones de madera recia, así como en los interiores de zaguanes adornados con pinturas murales, amplios patios empedrados, habitaciones espaciosas alumbradas con teatinas.

En este ambiente cargado de historia, bañado por el sol del desierto costero interrumpido por un valle perfumado de jugosos cañaverales y plantíos de piña, es donde nace Gerardo Chávez el 16 de noviembre de 1937, hijo menor de la humilde y numerosa familia de los Chávez López conformada por el pa-dre, la madre y once hermanos. En su primera infancia queda huérfano de madre, espacio afectivo que jamás logra cubrir pues a los pocos meses una madrastra carente de afecto se hace cargo del pequeño, coartándolo en sus sueños y juegos infantiles. Así transcurre lentamente el tiempoen el cual Gerardo para ganar algo de dinero vende paletas de helado. A los catorce años marcha a Lima, un poco huyendo de esa vida, otro poco en busca de Ángel, su hermano pintor, entre tanto descubre su futuro incierto.

En el taller de suhermang queda impresionado por el ambiente mágico de perfumes, texturas, policromía, mientras Angel, que con magistral pincel lleva a la tela numerosas obras sin dibujo previo, lo envuelve con su conversación nutrida de enseñanza artística. Delante de Gerardo pone las herramientas básicas del pintor, animándolo a realizar su primera obra, sin ocultarle por ello la difícil vida de un artista. Así lo introduce lentamente en un misterioso mundo sensorial en el cual aprende a gozar el olor de la trementina y de los óleos, a sentir la suavidad de los pelos de marta de los pinceles, la urdimbre del lino que sirve de soporte al cuadro, la densidad de los aceites, pinturas, diluyentes, a saborear, con sumo cuidado, los venenosos líquidos que le sirven de base para darle densidad a su paleta pictórica, a escuchar el imperceptible sonido del pincel, la espátula o los dedos mezclando colores o impregnando la tela, a visualizar los colores, tonalidades, contrastes que nacen segundo a segundo de las mixturas que él mismo elabora.

Por aquel tiempo el ambiente artístico peruano se encuentra muy tenso. Aproximadamente en 1943 , la presencia de nuevos planteamientos pictóricos 
comienza a desplazar a la llamada "Escuela Indigenista", movimiento generado por José Sabogal a partir de 1920, interesado en rescatar los valores culturales nacionales. Para la década de los cincuenta la abstracción está asentada gracias al impulso dado por el cubano José Gómez Sicre, representante de la Unión Panamericana en América Latina, entidad norteamericana con sede en Washington que pretende uniformizar el arte latinoamericano. Sin embargo, a pesar de las presiones que significan jerarquía, oportunidad de exponer en la Bienal de Sao Paulo creada exprofesamente para ello, becas de perfeccionamiento en Estados Unidos, apertura a la red comercial vía galerías de arte como "Cultura y Libertad", presencia en la prensa, la mayor parte de los artistas nacionales no entran en el juego amarrado por un cerrado grupo minoritario que en bloque intenta espantar a sus colegas. Así pasan a formar parte de la más cruel indiferencia por el lado de la crítica local, razón por la cual muchos de ellos optan por el autoexilio hacia Europa, en busca de otros ambientes culturales donde la discusión no sea arbitraria y puedan ellos realizar su propia obra sin paradigmas establecidos; un segundo grupo se queda a luchar palmo a palmo el espacio artístico nacional en una gran desventaja pues carecen de medios para enfrentarse a la maquinaria impuesta; eso no los calla, siguen produciendo en el silencio de su taller obras figurativas que se deslizan con modestia en el mercado interno, sin la parafernalia teatral.

En este ambiente, cuando contaba con diecisiete años de edad (1954) Gerardo ingresa a la Escuela Nacional de BellaseArtesşespacio académico en donde con rapidez sobresale Pertenece a la "Promoción Oro", denominada así pues todos sus integrantes destacan en el panorama plástico. Ante la perspectiva que le espera en Lima, prefiere emigrar a Italia donde presenta dos exposiciones individuales (Florencia y Roma); es en la segunda de ellas, en el verano de 1962, cuando el director de la Galería Obelisco le presenta al pintor chileno Roberto Matta, que entusiasmado por su obra le dice: "Tú estás loco de permanecer aquí, ven a París".

En la Ciudad Luz, Gerardo es un desconocido en el complejo ambiente cultural, donde se desenvuelven miles de artistas procedentes de diferentes lugares; entonces lucha cada centímetro para conformar su propio espacio. La tarea no es sencilla, se necesita de una increíble capacidad creativa, dominio pleno del oficio, además de contar con una red social que le permita adentrarse en este mundo. En los inicios para poder mantenerse, realiza trabajos eventuales sin dejar en ningún momento sus pinceles, como tampoco su compromiso político nacido en las aulas de Bellas Artes, enfatizado por el triunfo de la Revolu- 
ción Cubana. No resulta extraño entonces, que en 1965, cuando las fuerzas armadas peruanas del gobierno de Fernando Belaunde Terry aplastan a la guerrilla organizada por el MIR matando a sus integrantes entre los que se encuentra De La Puente Uceda, Lobatón y Escobar, Gerardo pinte el tríptico L'etoile du matin, emotivo homenaje a los guerrilleros peruanos caídos en combate.

Es en 1968, después de entablar amistad con el cubano Wilfredo Lam con quien se enriquece gracias a las apasionadas conversaciones mantenidas durante horas, cuando Gerardo regresa al Perú en un momento de complicada coyuntura política y cultural que desemboca en el cambio de la democracia por la dictadura, la vuelta al timón de la derecha hacia la izquierda, la apertura de una política cultural gubernamental (primera en la historia) de tendencia nacional con un aparato estatal apoyado en las artes a fin de difun-dir sus programas políticos culturales; se trata del gobierno militar del gene-ral Juan Velasco Alvarado al cual ni la desgastada abstracción, ni el movimiento experimental, tienen la suficiente consistencia para enfrentar este cambio radical.

El retorno de Gerardo coincide con el de Tilsa Tsuchiya, su antigua compañera de aula, quien como él emplea como lenguaje el surrealismo; mientras Tilsa se inspira en la magia mitológiea, Gerardo usa, además, una sugerente fantasía nacida en lo onírico, en los juegos infantiles, en la realidad peruana, presentada en la primera muestra individual después desut partida, a la que titula El cierra los ojos, él ve. A partiradejestemomentó Sustazos con Perú se reafirman, por lo que de manera permanente realiza viajes uniendo tres ciudades París, Lima, Trujillo, en un todo coherente pero agobiador. Así en 1970, a raíz del terremoto que tiene como epicentro el Callejón del Huaylas, donde la ciudad de Huaraz queda en escombros en tanto la de Yungay desaparece al ser arrasada por un terrible huaico (alud de piedra y barro), Gerardo no puede permanecer indiferente. Junto a un grupo de artistas y escritores radicados en París, entre los que se hallan Manuel Scorza, Jorge Piqueras, Grati Piqueras, Hilda Gadea, organiza una exposición-venta de obras de arte donadas por artistas de renombre como Picasso, Dalí, Miró, Vasarely, Matta; los fondos obtenidos los envía al país por intermedio de la Embajada del Perú en Francia con la finalidad de ayudar a las víctimas del terremoto, cuyo número exacto jamás llega a conocerse.

Una de las facetas personales de Gerardo es romper estereotipos culturales en la encasillada sociedad peruana. En 1981 presenta en el Museo de Arte Italiano de Lima una retrospectiva de su labor plástica bajo el nombre 25 años de 
pintura de Gerardo Chávez; en esta oportunidad exhibe más de cien obras personales que causan un gran escándalo en el ambiente limeño, y en la pluma de una crítica mezquina, pues se trata de la primera exposición retrospectiva realizada a un artista vivo. No contento con esto organiza, coordina y dirige la Primera y Segunda Bienal de Arte en la Ciudad de Trujillo (1983, 1985), acontecimientos de gran trascendencia no sólo por su magnitud, sino por elegir como sede a la olvidada provincia. A estos encuentros son invitados un número representativo de artistas; en la primera se aprovecha la oportunidad para rendir homenaje a una escultora y a nueve pintores desaparecidos. La segunda congrega a artistas de diversas tendencias contemporáneas residentes en el Perú (45), en el extranjero (29), además de contar con la asistencia de seis invitados de países del Grupo Andino (Ecuador, Perú, Colombia, Venezuela y Bolivia); acuden asimismo críticos y gran cantidad de público interesado en el arte, ante lo que el mismo Gerardo comenta:

"Podemos decir que se trata esta vez de una reunión sin precedente que da inicio a una confrontación, en el ámbito de las artes plásticas, de las obras de los artistas más destacados que residen en nuestro medio con la obra de aquellos cuyas aspiraciones llevaron a atravesar con su arte las fronteras del país".

El anclaje con Perú cada día crece más. Ahora se trata de formar un museo de arte y otro de juguete en la ciudad de Trujillo, organizar una nueva bienal, compartir el arte con los niños en encuentros culturales, mientras intenta recuperar para la historia del arte peruano a decenas de artistas plásticos injustamente acallados por el estrueñdose éxitocdecunos pocos: $\mathrm{SO}$ \#

Así conozco a Gerardo Chávez. Durante dos años consecutivos nos reunimos los jueves al atardecer en su taller. Por esos días su meta es rescatar la figura de su hermano Ángel Chávez (1929-1995), uno de los más importantes pintores que al no querer integrarse a los parámetros de su tiempo, en la lucha por mantener su propio estilo y personalidad, es ignorado por la crítica que lapida, ignora o no lo quiere "ver", al estar enceguecida por héroes de barro.

Al llegar a su estudio lo sorprendo de pie frente al último cuadro; mientras retrocede para observar el conjunto o avanza a fin de insertar con fino pincel bañado en óleo o acrílico las quimeras de su fantasía, me platica de los últimos acontecimientos, de las ilusiones frustradas, de los escollos sorteados, de los sueños realizados, de los nuevos proyectos, en tanto yo parada frente al gran ventanal lo escucho sin interrumpirlo deleitándome con el parque a mis pies bañado por la fina lluvia limeña que lo envuelve con su capa gris; o deambulo 
por su estudio regocijando mi vista una y otra vez con los infinitos detalles de cada una de las obras allí detenidas silenciosamente esperando un toque de pincel o el momento oportuno para ser exhibidas a un público más amplio al cual le puedan cantar sus ensueños. Finalmente me siento en un banquito pegada al cuadro que trabaja, atenta a cada uno de sus movimientos y palabras. Después de limpiar sus pinceles, espátulas y paleta iniciamos el trabajo en el cual estamos empeñados. Y como dice Gerardo, empieza a "diarrear" sus ideas, experiencias, vivencia que meticulosamente voy ordenando de manera coherente tras su mirada acuciosa.

Gerardo Chávez es el símbolo de una vida agitada envuelta en el permanente torbellino de compromisos políticos, intereses intelectuales, emociones sentimentales, amigos descubiertos, fallecidos o reencontrados, fuertes impresiones permanentes, verdadero volcán en constante erupción. Gracias a su arte, la pintura convierte sus inquietudes en una libre interpretación de la realidad o de la fantasía envuelta en un juego policromado repleto de movimiento y sensualidad. Así nace, entre sus últimas obras, la serie La Procesión de la Papa, enormes cuadros de poco colorido, en donde con gran religiosidad los personajes, acompañados por una orquesta y seguidos de numerosos fieles, cargan en las andas al tubérculo milenarid que forma parte principal de la dieta peruana. El Ekeko es otro homenaje al mundo ancestral andino; esta vez se trata de la imagen de un pequeño dios del altiplano encarnación de la abundancia y de la prosperidad. La serie de lỏs daballitos muestrâ Iarnagia del carrusel que locamente gira sobre un mundo al derechöli al revés que puede estar arriba, abajo, invertido o como sea, conformado de cientos de inmuebles cuyos techos, alambres de alumbrado eléctrico, figuras, entorno nos recuerdan las poblaciones de la periferia limeña, donde se fabrican y venden toritos y castillos de fuegos artificiales para alegrar las fiestas religiosas populares.

La producción plástica de Gerardo, que ha pasado por diferentes etapas, posee un denominador común, el erotismo, planteado en ampulosas caderas, mimos sexuales entre los actores antropomorfos, besos furtivos, manos intrépidas que acarician a hurtadillas voluptuosos senos o prominentes nalgas que no le pertenecen, acciones que a veces desconciertan al espectador con la presencia de un inocente monito que con candidez forma parte de este loco mundo pletórico de figuras. Por su lado el espectador, si lo desea, puede ingresar a formar parte del conjunto gracias a diferentes puntos, los propios o los colocados a propósito por el mismo Gerardo en sugerentes puertas o ventanas abiertas por las que también se puede escapar hacia otro cosmos donde cada quien 
coloca su propio ensueño. $\mathrm{Y}$ es que en estos cuadros todo fluye, no existen limites, el planteamiento está dado en base a la libertad absoluta para que cada quien concluya con su propia fantasía.

La multitud de personajes que conforman sus ilimitadas composiciones, de carácter barroco, están distribuidas en torno a una figura principal; las otras se mueven retuercen, corren, esconden del observador, juegan, huyen o entran a la escena sorpresivamente, hacen el amor, dentro de un mundo fantástico capaz de ser planteado sólo por una mente surrealista.

A simple vista, sola, aislada de su contexto, cada cuadro es una obra de exquisita calidad, acabado dibujo, dominio del color y la técnica. Pero si se las analiza con el hilo conductor de su vida, las pinturas se convierten en el compromiso socio político y cultural de la etapa histórica que a Gerardo le toca vivir en Trujillo, Lima, América Latina y París. Y es que Gerardo no pertenece a ese grupo de artistas que se aísla de su realidad. Por el contrario, se zambulle en el escabroso mundo actual sin sobresaltos, al que le agrega la carga histórica del milenario pasado peruano y occidental, más todo aquello emanado de su propia sensibilidad. Por eso su producción plástica, hoy día de carácter internacional, es un exquisito espejo en el que se refleja la vida, la cultura y las emociones de nuestra humanidad, especialmente la latinoamericana.

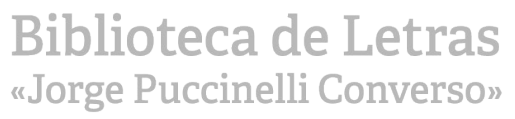

